\title{
Poultry Slaughterhouse Wastewater Treatment Plant Design Advancements
}

\author{
Maggie N. Bingo ${ }^{\mathrm{a}, \mathrm{b}}$, Moses Basitere ${ }^{\mathrm{a}, \mathrm{b}}$, and Seteno Karabo O. Ntwampe
}

\begin{abstract}
Poultry slaughterhouse wastewater (PSW) is usually disposed of by discharging it into watercourses, municipal wastewater treatment works (WWTWs), or by scattering it on grass and croplands. However, the hazardous nature of the PSW makes it injurious to human health and the environment. As a result, the South African Government has established a Waste Discharge Charge System (WDCS), which is based on the 'polluter pays' principle, as a means to encourage industrial waste dischargers to reduce their waste and use water resources optimally. Therefore, the poultry industry is required to adopt the latest technologies that will reduce freshwater consumption and increase reuse practices to achieve zero effluent discharges. This paper will present wastewater treatment options available, and give motivation as to why Sumo, which is a wastewater process simulator, should be applied to evaluate the performance of an anaerobic bioreactor.
\end{abstract}

Keywords - anaerobic treatment, mathematical modelling, poultry slaughterhouse wastewater, Sumo

\section{INTRODUCTION}

Over the past few decades, poultry meat consumption has increased drastically in many countries around the world, because of the rapid poultry growth rate [1], poultry meat is a great source of protein [2], and it is cheap for low-income families in developing countries [3]. In South Africa (SA), the total poultry meat production comprises of $93.6 \%$ broiler meat, and the remaining $6.4 \%$ consists of mature chicken slaughter, small-scale broiler, geese, turkey, duck and guinea fowl meat produce [4]. According to the South African Poultry Association (SAPA) [5], a total of 927.1 million broilers were slaughtered in 2017 , and since the average water consumption per bird ranges between $15-20 \mathrm{~L}$ [6], the water consumption of broiler slaughterhouses for 2017 ranged between 13.9 - 18.5 million $\mathrm{m}^{3}$. Unfortunately, about $90 \%$ of this water consumption is discharged as wastewater because it is used for washing meat products, also for sterilizing equipment, process and reception areas of the slaughterhouse [6], [7].

Wastewater generated by the slaughterhouse is classified as high strength wastewater for it contains large quantities of organic matter (nutrients, chemical oxygen demand [COD] and biological oxygen demand [BOD]), suspended solids (SS),

Manuscript received October 10, 2019. This work was supported in part by the CPUT under URF RK16, and BioERG under RK45.

${ }^{a}$ Department of Chemical Engineering, Faculty of Engineering and the Built Environment, Cape Peninsula University of Technology, P.O. Box 1906, Bellville, 7535, South Africa.

b Bioresource Engineering Research Group (BioERG), Cape Peninsula University of Technology, P.O. Box 652, Cape Town, 8000, South Africa. pathogens and fats, oil and grease (FOG) [8]. When discharged into water bodies the biodegradable organic matter causes a reduction in the surface water's dissolved oxygen (DO) which results in the death of aquatic life, increased growth in algae and higher forms of plant life, and the spreading of water-borne diseases [9]- [11]. Discharging PSW into WWTWs can damage the equipment [12], and spraying it onto cropland can become toxic for plants [10].

The water, wastewater management practices and industrial discharge standard regulations in SA are governed by the National Water Act [NWA] (Act 36 of 1998) and the Water Services Act [WSA] (Act 108 of 1997) [13]. The standards for water purification prior to discharge are provided by the NWA, whereas the guidelines and tariffs for water supply and effluent discharge are provided by the WSA [14]. As a means of ensuring that industries adhere to the stipulated discharge standards, the Waste Discharge Charge System (WDCS) was developed by the Department of Water Affairs (DWA). The WDCS made sure that waste dischargers are penalized when their waste does not meet the discharge standards and financially incentivized when they minimize their waste and use water resources optimally [15]. The application of the WDCS is based on the source of the discharge, the characteristics of the wastewater, and the affordability of monitoring different variable, such as nitrate $\left(\mathrm{NO}_{3}^{-}\right)$, orthophosphate $\left(\mathrm{PO}_{4}{ }^{3-}\right)$, ammonia $\left(\mathrm{NH}_{4}^{+}\right)$, sulfate $\left(\mathrm{SO}_{4}{ }^{2-}\right), \mathrm{COD}$ and BOD to name a few. As indicated by Table I, PSW has to undergo a great deal of treatment in order to meet the effluent discharge standards [16].

TABLE I: CHARACTERISTICS OF PSW IN THE WESTERN CAPE AND EFFLUENT DISCHARGE STANDARDS [17], [18]

\begin{tabular}{lrr}
\hline \hline & \multicolumn{1}{c}{$\begin{array}{c}\text { Poultry } \\
\text { Slaughterhouse } \\
\text { Wastewater }\end{array}$} & $\begin{array}{c}\text { Standards } \\
\text { for effluent } \\
\text { discharge }\end{array}$ \\
\hline \multicolumn{1}{c}{ Parameter } & \multicolumn{1}{c}{ Range } & $\begin{array}{c}\text { General } \\
\text { Limits }\end{array}$ \\
\hline $\mathrm{pH}$ & $6.5-8.0$ & $5.5-9.5$ \\
$\begin{array}{l}\text { Total COD } \quad \text { [tCOD] } \\
(\mathrm{mg} / \mathrm{L})\end{array}$ & $2133-9695$ & 75 \\
$\begin{array}{l}\text { Total Kjeldahl Nitrogen } \\
{[\mathrm{TKN}](\mathrm{mg} / \mathrm{L})}\end{array}$ & $77-352$ & 15 \\
$\mathrm{NH}_{4}-\mathrm{N}(\mathrm{mg} / \mathrm{L})$ & $29-51$ & 6 \\
$\mathrm{PO}_{4}-\mathrm{P}(\mathrm{mg} / \mathrm{L})$ & $8-27$ & 10 \\
$\mathrm{FOG}(\mathrm{mg} / \mathrm{L})_{\mathrm{Total} \mathrm{Suspended} \mathrm{Solids}}$ & $131-684$ & 2.5 \\
{$[\mathrm{TSS}](\mathrm{mg} / \mathrm{L})$} & $315-4992$ & 25 \\
$\mathrm{NO}_{3}-\mathrm{N}(\mathrm{mg} / \mathrm{L})$ & $0-2.903$ & 1.5 \\
\hline \hline
\end{tabular}




\section{MethodS AND SOFTWARE DESIGN}

\section{A. Poultry Slaughterhouse Wastewater Treatment Methods}

Due to the composition variations of PSW, the treatment plants are said to be dynamic [19], as a result, the treatment methods require a combination of processes that will treat and disinfect the wastewater on-site [20]. These methods are similar to those used at municipal WWTWs and comprise of 1) pre-treatment, 2) primary, 3) secondary, and 4) tertiary treatment processes [21]. Treatment selection is dependent on the characteristics of the wastewater, the available technology and adherence to the discharge standards [22].

\section{1) Pre-treatment methods}

Screening, settling, catch basins, and floatation systems are pre-treatment options practised in poultry slaughterhouses. The screening process is typically the first, simplest and most economical form of treatment that recovers offal materials (e.g. feathers, meat particles, bones, protein, and FOG), which is then treated as solid waste that can be used in the poultry rendering industry [14], [21]. The screening process is capable of removing up to $60 \%$ solids and $30 \%$ BOD, however, mechanical failure and blanking can result from overloading the screen or the under-sizing of screen gaps [22]. There is a wide range of screens available such as stationery or incline screens, rotary cylindrical screens, brushed screens and vibrating screens, therefore, the particle size of solids to be removed determine the type of screen to be used [14].

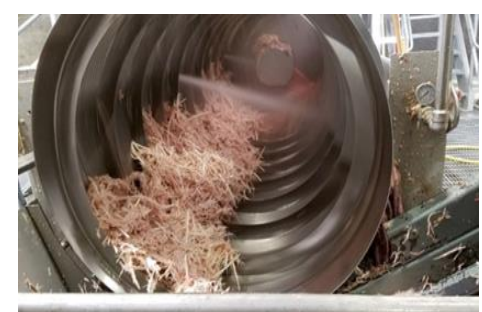

Fig. 1. Rotary cylindrical screen used at a poultry slaughterhouse in Virginia, United State of America (USA) [23].

Thereafter, catch basins and settling tanks are used to remove fine SS and FOG by means of gravity. The particles denser than water collect at the bottom of the tank as sludge and are removed with a scraper, whereas the fine solids and FOG rise to the surface where they are skimmed off [21]. According to Bustillo-Lecompte and Mehrvar [22], these systems have a BOD and soluble solids removal efficiency of $30 \%$ and $70 \%$ respectively. The scum that is skimmed off can be used as animal feed or processed as raw material for manufacturing soaps and cosmetics [14].

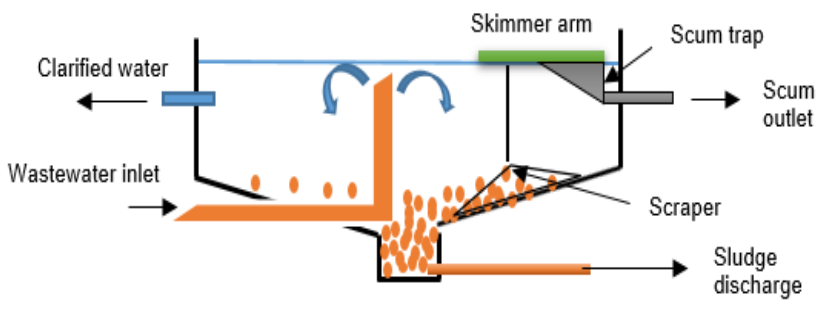

Fig. 2. Schematic illustration of a settling tank.

\section{2) Primary treatment process}

Primary treatment processes are physico-chemical systems that further remove total suspended solids (TSS) and FOG from the wastewater [13], as well as reduce COD and BOD content [21]. Dissolved air flotation [DAF] systems are commonly used as a primary treatment process for PSW even though there are systems that can achieve similar results at low-cost [24]. In the DAF unit, a portion of the treated wastewater is recycled from a point downstream of the DAF, retained for a few minutes in a pressure vessel for mixing and air saturation to occur, and then injected through the bottom of the DAF unit. When the pressure drops causing the air to come out of solution, fine bubbles are created which carry light solids and FOG to the surface where the resulting scum is skimmed off [25]. The performance of the DAF is improved when coagulants (e.g. aluminum sulfate $\left[\mathrm{Al}_{2}(\mathrm{SO} 4) 3\right]$ and ferric chloride $\left.\left[\mathrm{FeCl}_{3}\right]\right)$ and/or flocculants (e.g. polymers) are mixed with the pre-treated wastewater prior to entering the DAF for they promote clattering, precipitation and fat flotation. It has been reported that the DAF removes 30-90\% COD and 70-90\% BOD, and large amounts of nutrients. Nonetheless, DAFs are systematically malfunctioning and have insufficient separation with regards to TSS [22].

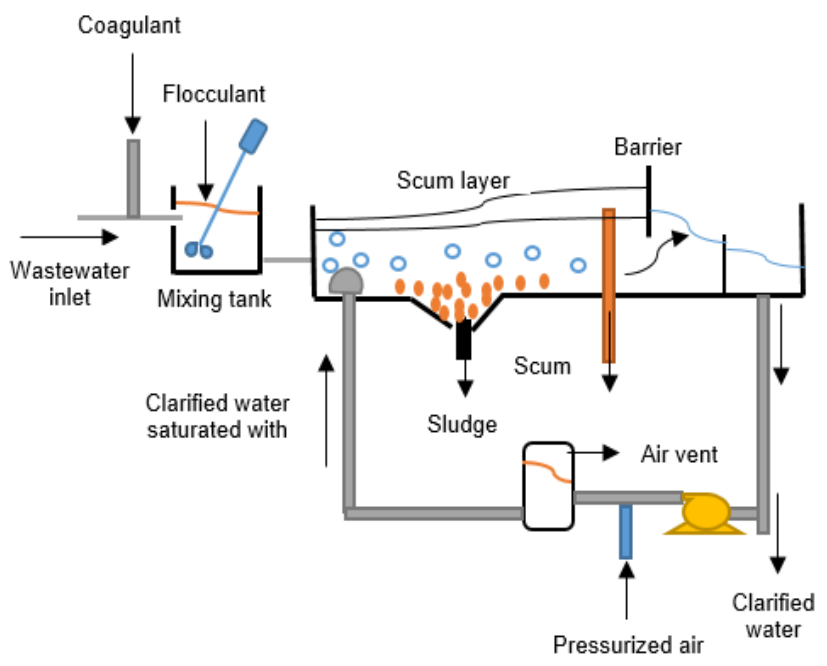

Fig. 3. Schematic diagram of a DAF clarifier unit.

\section{3) Secondary treatment process}

Secondary treatment processes are biological systems, namely anaerobic and aerobic, that reduce the concentration of organic material and deactivate pathogens using bacteria [8]. Anaerobic treatment has been identified as the ideal biological treatment due to its success in treating high strength wastewater with less multifaceted equipment requirements, high removal of COD, and methane production which is capable of counterbalancing the energy costs of abattoir [20], [26].

This treatment system operates as a two-stage fermentation process which occurs simultaneously in the absence of oxygen, where in the first stage anaerobic bacteria degrade organic compounds into volatile fatty acids (VFA), carbon dioxide $\left(\mathrm{CO}_{2}\right)$, water, hydrogen gas $\left(\mathrm{H}_{2}\right)$, hydrogen sulphide $\left(\mathrm{H}_{2} \mathrm{~S}\right)$ and ammonia $\left(\mathrm{NH}_{3}\right)$, and the second stage is the production of methane $\left(\mathrm{CH}_{4}\right)$. The participation of microorganisms aids the 
use of appropriate organic substrates [8], [14]. There is a wide selection of anaerobic treatment units, and each process has unique treatment benefits and operating restrictions [8].

In anaerobic baffled reactor (ABR) there is better interaction between the wastewater and active biomass because of the series of compartments and baffles, and this causes high biodegradation [22].

The up-flow anaerobic sludge blanket (UASB) bioreactor is one frequently used anaerobic digestion (AD) reactors for wastewater treatment. However, considerable wastewater pre-treatment is required before entering the UASB reactor due to its sensitivity to fats and other organic material [26]. The design of the static granular bed reactor (SGBR) is based on the UASB reactor but with a down-flow configuration intended to facilitate the separation of wastewater, solids, and biogas [27]. The expanded granular sludge bed (EGSB) is also founded on the design of the UASB but with better organic loading rates (OLRs), production of gas, soluble pollutants removal, and enhanced mixing in the reactor [28]. These technologies have been widely applied in wastewater treatment [27].

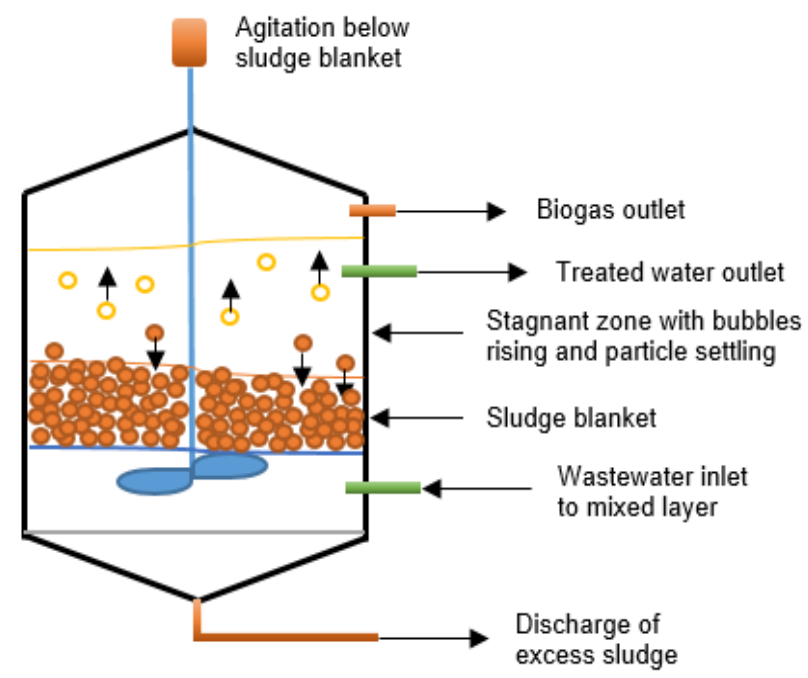

Fig. 4. Schematic diagram of a UASB bioreactor.

The effluent of anaerobic digesters still encompasses soluble organic matter and nutrients which can be effectively treated by aerobic methods, and as a result aerobic treatment, which operates at rates higher than anaerobic methods, is applied as post-treatment for anaerobic effluent. The advantages of this treatment method include reducing odours, speedy biological growth rates, and quick modifications to temperature and loading rate changes [20]. However, aerobic treatment has a high energy requirement due to aeration and high sludge [29]. In aerobic systems organic substrates are degraded by microorganisms which need free DO, therefore oxygen is administered by force either with mechanical aerators or compressors with diffusers or by passing the effluent down a trickling filter to come in contact with atmospheric oxygen. The carbohydrates present in the wastewater are oxidised to form $\mathrm{CO}_{2}$ while nitrogenous wastes form $\mathrm{NO}_{3}{ }^{-}$and $\mathrm{SO}_{4}{ }^{2-}$ [6]. Treated wastewater is displaced by incoming effluent into clarifying tanks where some of the settled sludge is recycled to the aerated basin for the maintenance of microbial culture in peak conditions as depicted in Fig. 5, while the rest is disposed into landfill sites or spread over agricultural land after further treatment. At this point, the treated wastewater can be discharged into water bodies. There is a selection of aerobic treatment methods available such as aerobic lagoons, activated sludge (AS) processes (extended aeration, oxidation ditches, and sequencing batch reactors), and trickling filters [14].

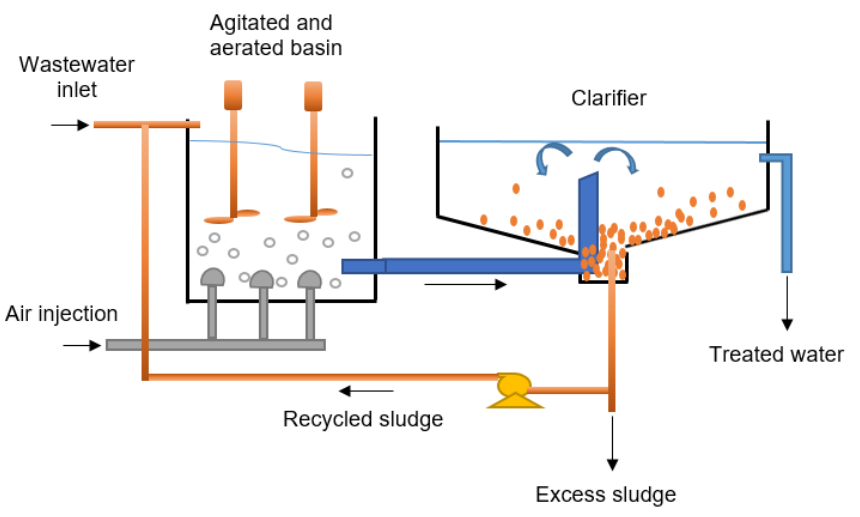

Fig. 5. Illustration of an AS wastewater treatment system.

Aerobic lagoons are large, shallow ponds in which the sunlight, algae, bacteria and oxygen interact to treat wastewater. This process takes between 2-6 days for complete treatment and can achieve up to $90 \%$ reduction of BOD [30]. The AS processes are considered to be economical, and use either the adsorption or oxidation of organic matter application. Nevertheless, these systems have been reported to produce inadequate settling flocs when treating SWW due to the presence of fats and low DO levels and require extended aeration for the minimization of sludge production [22]. Trickling filters consist of tanks containing porous media with a high surface volume ration, where wastewater is fed from the top of the tank. The organic matter and $\mathrm{N}_{2}$ remaining in the influent encourages the growth of bacteria on the media [6]. The maximum removal efficiency of BOD attained by this treatment process is $90 \%$, and it further removes the residual SSs [30].

\section{4) Tertiary treatment methods}

If the purpose of the treatment process is to recycle the treated water within the slaughterhouse for poultry meat processing tertiary treatment processes can be implemented [31], to remove suspended or dissolved substances that could not be completely removed by the secondary treatment processes [32]. Tertiary treatment processes that are utilized for treating PSW include advanced oxidation processes (AOPs), and membrane filtration systems and these processes are considered to be highly expensive [6]. The AOPs are founded on physico-chemical processes that produce powerful oxidative species which enables the oxidation and degradation of organic matter without the use of additional chemicals that might result in the formation of harmful by-products [20], [33]. Membrane processes are considered to be ideal for disinfection and water polishing, to a point where the treated water meets the standards of portable water for they are exceptional at removing small particles, and residual $\mathrm{N}$ and $\mathrm{P}$. Even though membrane filtration does not require temperature monitoring, the presence of FOG may result 
in clogging of the membrane [17].

This paper will focus on the secondary treatment process, more specifically, anaerobic treatment. The metabolic process of anaerobic digesters is discussed under the next subheading.

\section{B. Simulation Software Methods: SUMO Application}

Developing a mathematical model can contribute to enhancing and monitoring a specific environmental process more efficiently since it allows the role and effect of significant parameters to be examined. The accuracy and dependability of accessible experimental data, the nature of the wastewater being treated together with the biochemical reactions involved determine the value of modelling [28], [37]. The efficacy of anaerobic reactors is affected by reactor flow patterns, loading rates, the existence of toxic compounds, mass transfer in the biofilm and kinetic effects. There are a number of models available for $\mathrm{AD}$, however, each kinetic model is only applicable for specific cases and processes [38].

There is a wide variety of available wastewater treatment modelling packages, with a majority being founded on the Activated Sludge Model (ASM). A number of these software packages assume steady-state and are run utilizing average day flows and loads. This is called steady-state modelling and is appropriate for checking process unit sizes and executing basic fault findings of treatment processes [40]. Nutt et al. [40] mentioned that more advanced software packages can perform dynamic modelling using varying conditions over hours, days, weeks or year. This type of modelling provides more information on the performance of treatment process over a period of time.

SUMO is a full-featured wastewater treatment process simulator software developed by Dynamita for environmental models, principally for municipal and industrial WWTP modelling. It is capable of simulating biokinetic models dynamically or in steady-state, as well as direct algebraic and mixed equilibrium-kinetic models subject to the simulation mode. Sumo consists of internally researched and developed whole plant and focused models including ASMs models for $\mathrm{N}$ and $\mathrm{P}$ removal. SUMO is perfect for investigating key elements of treatment systems and detecting anaerobic digester system reactions for long-term differences of the feed load [19]. Furthermore, it has a user-friendly interface and open-source process codes which furnish the end-user with a better understanding of the calculations behind the model [41]. Furthermore, unlike other software packages which have an annual licensing fee, SUMO has a once-off licensing fee, therefore, making it economical.

A differential equation system using Peterson matrix is the foundation for dynamic modelling and contains processes that cause the change of state variables. SumoSlang (SUMO Simulation Language) is an Excel-based source code language in which SUMO models are written, and these models are accountable for the descriptions of the operational units. The SumoSlang files encompass the physical and technological parameters as well as the mass balance calculations for each unit [19]. The steps that will be followed to develop the model that will be explored in the current study are listed below [19], [40]:

1. Determining the model to be applied and required outputs.
2. Configuring the specific treatment plant in the model.

3. Collecting appropriate data to populate and standardize the model.

4. Model calibration.

5. Model verification.

6. Finally, apply the developed model.

\section{DISCUSSION}

\section{A. The Metabolic Process of Anaerobic Digesters}

The AD of complex polymers in PSW is catabolized by a cluster of microorganisms through a biochemical process that consists of four stages: hydrolysis, acidogenesis, acetogenesis and methanogenesis. Hydrolysis is considered to be the first stage and involves the degradation of complex polymers (i.e. carbohydrates, proteins and fats) into sugar, amino acids and long-chain fatty acids [34]. Due to the formation of non-desirable volatile fatty acids (VFA), hydrolysis is considered to be the rate-limiting step for organic substrates degradation [35]. The hydrolysis products are then converted into $\mathrm{CO}_{2}, \mathrm{H}_{2}, \mathrm{NH} 3, \mathrm{H}_{2} \mathrm{~S}$, alcohols and VFAs (i.e. short-chain fatty acids, namely acetate $\left[\mathrm{CH}_{3} \mathrm{COO}^{-}\right]$, propionate $\left[\mathrm{CH}_{3} \mathrm{CH}_{2} \mathrm{COOH}\right]$ and butyrate $\left.\left[\mathrm{C}_{4} \mathrm{H}_{7} \mathrm{O}_{2}{ }^{-}\right]\right)$by fermentative or acidogenic bacteria, and this second stage is called acidogenesis [13], [17]. During the third stage, acetogenesis, acetogens convert organic acids and alcohols into more $\mathrm{CH}_{3} \mathrm{COO}^{-}, \mathrm{CO}_{2}$ and $\mathrm{H}_{2}$ in order to maximize the production of $\mathrm{CH}_{4}$ [34]. As mentioned by Williams [17] there is a possibility of degrading $\mathrm{CH}_{3} \mathrm{COO}^{-}$when there are sulfate-degrading organisms present, and that the formation of $\mathrm{CH}_{3} \mathrm{COO}^{-}$can be hindered by the accumulation of $\mathrm{H}_{2}$ generation during the acetogenesis stage. Fortunately, methane-forming bacteria consume the $\mathrm{H}_{2}$ to generate $\mathrm{CH}_{4}$. The fourth and final stage of $\mathrm{AD}$ is methanogenesis where $\mathrm{CH}_{4}$ is formed by either converting acetic acid $\left(\mathrm{CH}_{3} \mathrm{COOH}\right)$ molecules using acetrophic methanogens or through the reduction of $\mathrm{CO}_{2}$ by hydrogenotrophic methanogens [34].

The biogas produced by the AD process contains $50-75 \%$ $\mathrm{CH}_{4}, 25-45 \% \mathrm{CO}_{2}$, and traces of carbon monoxide (CO), $\mathrm{H}_{2} \mathrm{~S}$, $\mathrm{NH}_{3}$, oxygen $\left(\mathrm{O}_{2}\right)$ and water vapour [34]. Biogas can be utilised as combustible fuel in combined heat and power (CHP) gas engines or processed further to produce natural gas-quality biomethane. The remaining material after $\mathrm{AD}$ can be used as fertilizer for the bio-augmentation of agricultural soil [17]. The following section will briefly discuss the results obtained by other researchers who evaluated the performance of different anaerobic bioreactors.

\section{B. Studies Conducted by Other Researches}

\section{1) Experimental investigation of anaerobic digesters}

In a study conducted by Williams [17], a lab-scale EGSB reactor treating PSW was operated for 172 days with an average hydraulic retention time (HRT) of $49.8 \mathrm{~h}$ and OLR of $3 \mathrm{~g}$ COD/L.day. The EGSB achieved overall removal efficiencies of $69 \%, 98 \%$ and $92 \%$ with respect to tCOD, TSS and FOG respectively. In $2019 \mathrm{Al}$ Smadi et al. [26] conducted a study that 
assessed the performance of a $10.45 \mathrm{~L}$ ABR that was operated at temperatures ranging from $15-23^{\circ} \mathrm{C}$ for the first 103 days. The ABR achieved an average COD and TSS removal efficiencies of $70 \%$ and $33 \%$. During the remaining 49 days, the reactor was operated at $40^{\circ} \mathrm{C}$ resulting in the removal efficiencies increasing to $90 \%$ for the COD and 44\% for TSS. In 2019 Rinquest et al. [36] evaluated the performance of a lab-scale SGBR, coupled with a single-stage nitrification-denitrification (SND) bioreactor and ultrafiltration membrane module (ufMM). The average removal efficiencies accomplished by the SGBR were $80 \%$ tCOD, $95 \%$ TSS, $89 \%$ BOD and $80 \%$ FOG over 138 days. The HRTs operated from 24 to $96 \mathrm{~h}$, whereas the OLRs operated from 0.73 to $12.49 \mathrm{~g} \mathrm{COD/L.day.} \mathrm{For} \mathrm{the} \mathrm{up} \mathrm{scaling} \mathrm{of} \mathrm{these}$ reactors for industrial use, process simulation is required to determine the practicability of the reactor.

\section{2) Mathematical Modelling of Anaerobic Digesters}

Coskun et al. [39] investigated the treatment of antibiotic fermentation broth wastewater using a UASB, focusing on COD removal and methane production. The mathematical modelling tools used in this investigation were the modified Stover-Kincannon, first-order, substrate mass balance, and Van der Meer and Heertjies kinetic models. With an HRT of 13.3 days and an OLR ranging from 0.33 to $7.43 \mathrm{~kg} \mathrm{COD} / \mathrm{m} 3$.day, a 95.7\% COD removal was accomplished with a maximum yield of 3,700 L/day methane production, hence proving that the UASB was able to successfully treat antibiotic fermentation broth. Yetilmezsoy et al. [28] used the Adaptive Neuro-Fuzzy Inference System (ANFIS) based model to predict the effluent COD load from a full-scale EGSB. According to the descriptive statistical performance indicators used for validation, this model demonstrated very good accuracy in predicting the effluent COD. Yang et al. [27] established a three-dimensional Computational Fluid Dynamics (3D CFD) model that combined the hydrodynamics and biokinetics of an EGSB reactor treating synthetic municipal wastewater to determine the influence of influent distribution in reactor hydrodynamics, mass transfer and operation details at different points in the reactor. It was concluded that the 3D CFD model successfully predicted the even distribution of the influent. Response Surface Methodology (RSM) is a mathematical and statistical technique used by Williams [17] to predict the performance of an EGSB coupled with anoxic/aerobic hybrid side stream ultrafiltration membrane bioreactor used for treating PSW with respects to tCOD removal. RSM successfully determined the suitable model that suited the experimental data, and the optimum conditions for a maximum of $93 \%$ tCOD removal establish to be an OLR of $2 \mathrm{~g}$ tCOD/L.day OLR and HRT of 4.82 days.

\section{CONCLUSION}

No study has been reported with respect to investigating the use of SUMO in predicting the performance of an EGSB treating PSW in South Africa, more specifically Cape Town. For this reason, Sumo will be applied to investigate the performance of the EGSB with regards to the removal of TSS, FOG in addition to the removal of COD. The results obtained by the simulation will be compared to experimental data.

\section{ACKNOWLEDGMENT}

The authors acknowledge the Cape Peninsula University of Technology (CPUT), as well as the Bioresource Engineering Research Group (BioERG) for their financial support that has made it possible for the current study to be conducted. The amazing drive, guidance and support provided by Dr Moses Basitere and Prof Seteno Ntwampe can never go unnoticed, and it is highly appreciated.

\section{REFERENCES}

[1] S. Barbut, Poultry Products Processing: An Industry Guide, New York, USA: CRC Press LLC, 2002, ch. 1, pp. 1-2.

[2] S. Roberts. (May 2017). Competition and industrial policies relating to food production in southern Africa, Working Paper Series $\mathrm{N}^{\circ} 255$. African Development Bank. pp. 12-14. Available: https://www.afdb.org/en/documents/publications/working-paper-series/

[3] S. M. Tan, H. L. de Kock, G. A. Dykes, R. Coorey and E. M. Buys (2018), "Enhancement of meat: Trends, nutritional profile, legislation and challenges," South African Journal of Animal Science, vol. 48, no. 2, pp. 199-212. https://doi.org/10.4314/sajas.v48i2.1

[4] Department of Agriculture, Forestry and Fisheries (2017), A Profile of the South African Broiler Market Value Chain, Pretoria, South Africa.

[5] South African Poultry Association (2017), Broiler Industry Stats Summary for 2017, pp. 1-15.

[6] N. A. Molapo, "Waste handling practices in the South African high-throughput poultry abattoirs," MTech., thesis, School of Agric. and Environ. Sci., Central University of Technology, Free State, South Africa, 2009.

[7] Department of Environmental Affairs and Development Planning (2015), Water Infrastructure and Opportunities for Agriculture and Agri-processing in the Western Cape, Western Cape, South Africa, pp. 40-43.

[8] M. Basitere, Z. Rinquest, M. Njoya, M. S. Sheldon and S. K. O. Ntwampe (2017), "Treatment of poultry slaughterhouse wastewater using a static granular bed reactor (SGBR) coupled with ultrafiltration (UF) membrane system," Water Science \& Technology, vol. 76, pp. 106-114. https://doi.org/10.2166/wst.2017.179

[9] J. H. Andersen, L. Schlüter and G. Frtebjerg (2006), "Coastal eutrophication: recent developments in definitions and implications for monitoring strategies," Journal of Plankton Research, vol. 28, pp. 621-628. https://doi.org/10.1093/plankt/fbl001

[10] P. Gerber, C. Opio and H. Steinfeld (2007), "Poultry production and the environment - a review," pp. 1-27.

[11] M. A. Yaakob, R. M. S. R. Mohamed, A. A. S. Al-Ghee and A. H. M. Kassim (July 2018), "Characteristics of chicken slaughterhouse wastewater," Chemical Engineering Transactions, vol. 63, pp. 637-642. Available: www.aidic.it/cet

[12] Department of Environment Affairs (2014), National Guideline for the Discharge of Effluent from Land-based Sources into the Coastal Environment, Pretoria, South Africa, RP101/2014.

[13] M. Basitere, "Performance evaluation of an up-and down-flow anaerobic reactor for the treatment of poultry slaughterhouse wastewater in South Africa," DEng. thesis, Dept. Chem. Eng., CPUT., Cape Town, South Africa, 2017

[14] G. Pocock and H. Joubert (September 2017), NATDURV 9: Water and waste water management in the poultry industry, $2^{\text {nd }}$ ed., Water Research Commission, South Africa, WRC Report No. TT 730/17. Available: www.wrc.org.za

[15] G. Pegram, D. Weston and S. Reddy (2014), "Implementation of the waste discharge charge system," Water Practice and Technology, vol. 9, no. 2, pp. 125-134. https://doi.org/10.2166/wpt.2014.013

[16] Department of Water and Sanitation (November 2015), Department of Water and Sanitation notice 1154 of 2015, Pretoria, South Africa, No. 39411. Available: www.dws.gov.za/projects/PERR

[17] Y. Williams, "Treatment of poultry slaughterhouse wastewater using an expanded granular sludge bed anaerobic digester coupled with 
anoxic/aerobic hybrid side stream ultrafiltration membrane bioreactor," MEng, thesis, Dept. Chem. Eng., CPUT, Cape Town, South Africa, 2017.

[18] Department of Water and Sanitation (September 2017), National norms and standards for domestic water and sanitation services, Government Gazette, No. 41100, pp. 82-181.

[19] Z. Gazsó, F. Hàzi, I. Kenyeres and L. Vàci (2017), "Full-scale wastewater treatment plant simulation for real-time optimization," Water Practice and Technology, vol. 12, no. 4, pp. 848-856. https://doi.org/10.2166/wpt.2017.091

[20] C. Bustillo-Lecompte and M. Mehrvar, "Slaughterhouse Wastewater: Treatment, Management and Resource Recovery," in Physico-Chemical Wastewater Treatment and Resource Recovery, R. Farooq and Z. Ahmad, Ed. London, United Kingdom: IntechOpen Limited, 2017, ch. 8, pp. 153-174 https://doi.org/10.5772/65499

[21] S. Mbulawa, "Bio-delipidation of pre-treated poultry slaughterhouse wastewater by enzymes from the wastewater isolates," MEng, thesis, Dept. Chem. Eng., CPUT, Cape Town, South Africa, 2017.

[22] C. Bustillo-Lecompte and M. Mehrvar (2015), "Slaughterhouse wastewater characteristics, and management in the meat processing industry: A review on trends and advances," Journal of Environmental Management, vol. 161, pp. 287-302. https://doi.org/10.1016/j.jenvman.2015.07.008

[23] A. Burrows and R. Reidy (November 2018), "Separation screens in offal processing," Filtration + Separation, vol. 55, no. 6, pp. 20-22. https://doi.org/10.1016/S0015-1882(18)30375-6

[24] G. S. Mittal (2006), "Treatment of wastewater from abattoirs before land application - A review," Bioresource Technology, vol. 97, no. 9, pp. 1119-1135. https://doi.org/10.1016/j.biortech.2004.11.021

[25] C. Banks and Z. Wang, "Treatment of Meat Wastes," in Handbook of Industrial and Hazardous Wastes Treatment, $2^{\text {nd }}$ ed. L. Wang, Ed. New York: Marcel Dekker Inc., 2006, ch. 15, pp. 685-718. https://doi.org/10.1201/9780203026519.ch15

[26] B. M. Al Smadi, W. Al-Hayek and H. A. Hajar (March 2019), "Treatment of Amman Slaughterhouse Wastewater by Anaerobic Baffled Reactor," International Journal of Civil Engineering. https://doi.org/10.1007/s40999-019-00406-5

[27] J. Yang, Y. Yang, X. Ji, Y. Chen, J. Guo and F. Fang (September 2015), "Three-Dimensional Modeling of Hydrodynamics and Biokinetics in EGSB Reactor," Journal of Chemistry, pp. 1-7. https://doi.org/10.1155/2015/635281

[28] K. Yetilmezsoy, H. Ozgun, R. K. Dereli, M. E. Ersahin and I. Ozturk (2015), "Adaptive neuro-fuzzy inference-based modelling of a full-scale expanded granular sludge bed reactor treating corn processing wastewater," Journal of Intelligent and Fuzzy Systems, vol. 28, pp. 1601-1616.

[29] A. J. G. Gomes, D. O. Atambo, K. K. Das, D. L. Cocke and K. P. Das (2018), "Electrochemical remediation of chicken processing plant wastewater,", Journal of Environmental Chemical Engineering, vol. 6, no. 5, pp. 6028-6036. https://doi.org/10.1016/j.jece.2018.09.039

[30] A. Irshad, S. Sureshkumar, B. V. Raghunath, G. Rajarajan and G. M. Kumar, "Treatment of Waste Water from Meat Industry," in Integrated Waste Management in India: Status and Future Prospects for Environmental Sustainability, M. Prashanthi and R. Sundaram, Ed. Switzerland: Springer International, 2016, pp. 251-264. https://doi.org/10.1007/978-3-319-27228-3_23

[31] C. Muro, F. Riera and M. C. Diaz, "Membrane Separation Process in Wastewater Treatment of Food Industry," in Food Industrial Processes Methods and Equipment, B. Valdez, Ed. London, United Kingdom, IntechOpen Limited, ch. 11, 253-280.

[32] Y. W. Kang, K. M. Mancl, and O. H. Tuovinen (2007), "Treatment of turkey processing wastewater with sand filtration," Bioresource Technology, vol. 98, pp. 1460-1466. https://doi.org/10.1016/j.biortech.2006.03.006

[33] M. I. Litter and N. Quici (2010), "Photochemical Advanced Oxidation Processes for Water and Wastewater Treatment," Recent Patents on Engineering, vol. 4, pp. 217-241. https://doi.org/10.2174/187221210794578574

[34] C. E. Manyi-Loh, S. N. Mamphweli, E. L. Meyer, A. I. Okoh, G. Makaka and M. Simon (2013), "Microbial anaerobic digestion (bio-digesters) as an approach to the decontamination of animal wastes in pollution control and the generation of renewable energy," International Journal of Environmental Research and Public Health, vol. 10, no. 9, pp. 4390-4417.

https://doi.org/10.3390/ijerph10094390

[35] H. Yuan and N. Zhu (2016), "Progress in inhibition mechanisms and process control of intermediates and by-products in sewage sludge anaerobic digestion," Renewable and Sustainable Energy Reviews, vol. 58, pp. 429-438. https://doi.org/10.1016/j.rser.2015.12.261

[36] Z. Rinquest, M. Basitere, S. K. O. Ntwampe and M. Njoya (2019), "Poultry slaughterhouse wastewater treatment using a static granular bed reactor coupled with single stage nitrification-denitrification and ultrafiltration systems," Journal of Water Process Engineering, vol. 29, pp. 1-7.

https://doi.org/10.1016/j.jwpe.2019.02.018

[37] D. Orhon and E. Çokör (1997), "COD Fractionation in Wastewater Characterization - The State of the Art," Journal of Chemical Technology and Biotechnology, vol. 68, no. 3, pp. 283-293. https://doi.org/10.1002/(SICI)1097-4660(199703)68:3<283::AID-JCTB $633>3.0 . \mathrm{CO} ; 2-\mathrm{X}$

[38] S. Martinez, V. Torretta, J. Minguela, F. Siñeriz, M. Raboni, S. Copelli, E. Rada and M. Ragazzi (2014), "Treatment of slaughterhouse wastewaters using anaerobic filters," Environmental Technology, vol. 35, no. 3, pp. 322-332. https://doi.org/10.1080/09593330.2013.827729

[39] T. Coskun, H. A. Kabuk, K. B. Varinca, E. Debik, I. Durak and C. Kavurt (2012), "Antibiotic Fermentation Broth Treatment by a pilot upflow anaerobic sludge bed reactor and kinetic modelling," Bioresource Technology, vol. 121, pp. 31-35. https://doi.org/10.1016/j.biortech.2012.06.102

[40] D. Nutt, S. Kumarasingham, M. McCoy and M. Mates (2004), "The Advantages of having a Biological Wastewater Treatment Model from a Water Company Perspective," Available: https://www.waternz.org.nz

[41] A. Kolovos, O. Kjorlaug and P. J. Nilsen, "Development and assessment of a model for Cambi"s solidstream process using 'Sumo' WWTP simulation software, presented at the European Biosolids and Organic Resource Conference, Edinburgh, Scotland, November 15-16, 2016.

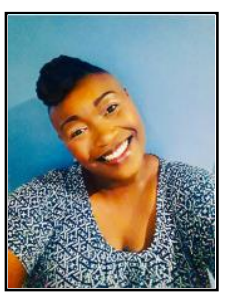

M.N. Bingo was born in Mahikeng in the North-West Province. In 2007 she completed a National Diploma in chemical engineering, and in 2008 she completed a BTech also in chemical engineering. She obtained these qualifications at the Cape Peninsula University of Technology (CPUT) in Cape Town, South Africa. Currently, she is pursuing a Master of Engineering qualification in chemical engineering part-time at the same institution, and her research focus is simulating the performance of a poultry slaughterhouse wastewater treatment system.

She is working as Laboratory Technician in the Chemical Engineering Department at CPUT and has lectured Chemical Engineering Technology 2 and Engineering Mathematics 2 during Winter/Summer school programs from 2017 to 2019.

During November 2019 Miss Bingo will be attending the IWA 2019 Innovation Conference on Sustainable Wastewater Treatment and Resource Recovery where she will be presenting a paper on Trinal Simulator Stages for Modelling of Poultry Slaughterhouse Wastewater Nutrient Removal. The conference committee has invited her to submit the aforementioned paper to the Bioresource Technology journal for publishing. 